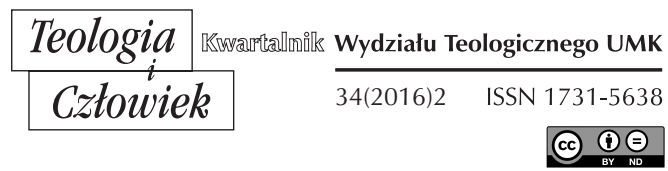

KS. RYSZARD SELEJDAK*

RZYM

\title{
POSŁUGA MIŁOSIERDZIA NAJBARDZIEJ TYPOWA DZIAŁALNOŚCIĄ DIAKONÓW STAŁYCH
}

DOI: http://dx.doi.org/10.12775/TiCz.2016.015

\section{WPROWADZENIE}

Diakon na mocy przyjętych święceń jest powołany do działania na podobieństwo Chrystusa Sługi ${ }^{1}$. Odwieczny Syn Boży „ogołocił samego siebie, przyjąwszy postać sługi” (Flp 2,7) i żył tak w posłuszeństwie Ojcu (por. J 4,34) oraz w pokornej służbie braciom (por. J 13,14). Chrystus swoją działalność służebną (por. Mt 20,28; J 13,1-7; Flp 2,7-8; 1 P 2,21-25) polecił kontynuować swoim uczniom (por. J 13,34-35). Na prośbę

* Ks. Ryszard Selejdak - dr hab. teologii, ur. 17 stycznia 1958 r. w Kromołowie, prezbiter archidiecezji częstochowskiej, patrysta i teolog dogmatyk. Doktorat z teologii patrystycznej - 1991 r. (Papieski Instytut Patrystyczny „Augustinianum” w Rzymie), habilitacja z teologii dogmatycznej - 2011 r. (Uniwersytet Kardynała Stefana Wyszyńskiego w Warszawie). Od 15 maja 1991 r. pracownik watykańskiej Kongregacji Edukacji Katolickiej. Od 1 marca 2002 r. dyrektor Departamentu Seminariów tej Kongregacji. Od 22 kwietnia 2013 r. dyrektor Departamentu Seminariów watykańskiej Kongregacji ds. Duchowieństwa (r.selejdak@virgilio.it).

1 Por. Kongregacja ds. Duchowieństwa, Dyrektorium o postudze i życiu diakonów stałych, 22.02.1998, Watykan 1998 (dalej: DPŻDS), n. 11. 
matki synów Zebedeusza, aby synowie zasiedli w Jego królestwie jeden po prawej, a drugi po lewej stronie, Jezus odpowiedział, iż nie wiedzą, o co proszą, i nie do Niego należy podejmowanie decyzji w tej sprawie, ale do Jego Ojca. Co więcej, wykorzystał okazję, aby upomnieć nieco zazdrosnych Apostołów, zwracając się do nich: „Lecz kto by między wami chciał stać się wielkim, niech będzie waszym sługą. A kto by chciał być pierwszy między wami, niech będzie niewolnikiem waszym" (Mt 20,26-27). Jezus zakończył swoją wypowiedź słowami wspaniałymi i jednocześnie niezwykle wstrząsającymi: „Syn Człowieczy [...] nie przyszedł, aby $\mathrm{Mu}$ służono, lecz aby służyć i dać swoje życie jako okup za wielu” (Mt 20,28). W słowach tych został ukazany z całą ostrością kontrast pomiędzy władzą i służbą. Władza przejawia się w służbie na rzecz drugich. Umycie nóg Apostołom przez Jezusa konkretyzuje dobrze tę bezinteresowną i całkowitą służbę (por. J 13,4-5). Jezus zostawia następnie precyzyjne przykazanie: „Jeżeli więc Ja, Pan i Nauczyciel, umyłem wam nogi, to i wy powinniście sobie nawzajem umywać nogi. Dałem wam bowiem przykład, abyście i wy tak czynili, jak Ja wam uczyniłem” (J 13,14-16). W Liście do Filipian, św. Paweł ukazuje Jezusa, który swoją służbę wobec ludzi wykonuje z pełną wolnością, pokorą oraz posłuszeństwem Ojcu aż do śmierci i to śmierci na krzyżu. Jezus Chrystus „istniejąc w postaci Bożej, nie skorzystał ze sposobności, aby na równi być z Bogiem, lecz [...] przyjąwszy postać sługi [...] uniżył samego siebie, stając się posłusznym aż do śmierci - i to śmierci krzyżowej (Flp 2,6-8). Taka służba Jezusa wobec drugich stanowi przykład do naśladowania dla Jego uczniów².

Diakon, będąc uczestnikiem jedynej posługi kościelnej, jest w Kościele specjalnym znakiem sakramentalnym Chrystusa Sługi ${ }^{3}$.

Sobór Watykański II w konstytucji dogmatycznej o Kościele Lumen gentium przedstawia posługę diakońską w potrójnym wymiarze, jako „diakonię liturgii, słowa i miłości”" Ten ostatni wymiar posługi diakońskiej bywa nazywany też diakonią miłosierdzia i najlepiej charakteryzuje

2 Por. M. Cancouét, B. Violle, I diaconi. Vocazione e missione, Bologna 1992, s. 35.

${ }_{3}^{3}$ Por. Kongregacja Edukacji Katolickiej, Wytyczne dotyczące formacji diakonów stałych, 22.02.1998, Watykan 1998 (dalej: WDFDS), n. 5.

${ }^{4}$ Sobór Watykański II, Lumen gentium. Konstytucja dogmatyczna o Kościele, 21.11.1964, w: Sobór Watykański II, Konstytucje, Dekrety, Deklaracje, Poznań 2002 (dalej: KK), n. 29. 
tożsamość i misję diakonów stałych. Stąd diakoni winni przede wszystkim pełnić dzieła miłosierdzia wobec potrzebujących na wzór Chrystusa Sługi. Zostaje im to przypomniane przez biskupa w Modlitwie święceńn ${ }^{5}$. Diakoni przez swoje życie i słowo winni też pomagać wiernym w podejmowaniu stałej służby braciom ${ }^{6}$.

\section{USTANOWIENIE "SIEDMIU" DO POSŁUGI PRZY STOŁACH (DZ 6,1-7)}

Święty Łukasz opisuje w Dziejach Apostolskich (6,1-7) ustanowienie „siedmiu”:

Wówczas, gdy liczba uczniów wzrastała, zaczęli helleniści szemrać przeciwko Hebrajczykom, że przy codziennym rozdawaniu jałmużny zaniedbywali ich wdowy. „Nie jest rzeczą słuszną, abyśmy zaniedbywali słowo Boże, a obsługiwali stoły" - powiedziało Dwunastu, zwoławszy wszystkich uczniów. „Upatrzcież zatem, bracia, siedmiu mężów spośród siebie, cieszących się dobrą sławą, pełnych Ducha i mądrości! Im zlecimy to zadanie. My zaś oddamy się wyłącznie modlitwie i posłudze słowa". Spodobały się te słowa wszystkim zebranym i wybrali Szczepana, męża pełnego wiary i Ducha Świętego, Filipa, Prochora, Nikanora, Tymona, Parmenasa i Mikołaja, prozelitę z Antiochii. Przedstawili ich Apostołom, którzy modląc się włożyli na nich ręce. A słowo Boże rozszerzało się, wzrastała też bardzo liczba uczniów w Jerozolimie, a nawet bardzo wielu kapłanów przyjmowało wiarę.

Tradycja Kościoła od samego początku widziała w powołaniu „siedmiu” ustanowienie „diakonatu” w Kościele ${ }^{7}$. Zostali oni przeznaczeni

5 Por. Pontyfikat rzymski. Obrzędy święceń biskupa, prezbiterów i diakonów, Katowice 1998, n. 277, s. 201.

${ }^{6}$ Por. R. Selejdak, Diakonat stały w świetle dokumentów Soboru Watykańskiego, posoborowego Urzędu Nauczycielskiego Kościoła i narodowych „Rationes institutionis diaconorum permanentium", Warszawa 2010, s. 324.

7 Por. Ignacy Antiocheński, Epistula ad Trallianos, II, 3, w: Patres Apostolici, red. F.X. Funk, Tubingae 1901 (dalej: PA) I, 245; Ireneusz, Adversus haereses, III, 12, 10, w: Patrologiae cursus completus. Series Graeca, wyd. J.P. Migne, Paris 1882, t. 7 (dalej: PG), 904-905; G. Schneider, Die Apostelgeschichte, Freiburg-Basel-Wien 1980, s. 417-419. 
do „obsługiwania stołów” w zastępstwie Dwunastu, którzy pragnęli całkowicie poświęcić się „modlitwie” i „posłudze słowa”.

\subsection{PROBLEM TOŻSAMOŚCl „SIEDMIU"}

Uważna lektura wspomnianego tekstu z Dziejów Apostolskich nasuwa jednak kilka wątpliwości w tym względzie.

Pierwsza to fakt, że św. Łukasz, pomimo, że redagował Dzieje Apostolskie w czasie, w którym „diakoni” już istnieli jako instytucja kościelna (por. Flp 1,1), nie posługuje się w ogóle rzeczownikiem diákonos na określenie „siedmiu” ani odpowiednio rzeczownikowej formy diakonía dla wyrażenia ich specyficznej posługi. Istotnie, termin diakonía oznacza zarówno posługę niesienia pomocy wdowom hellenistów $(\mathrm{Dz} 6,2)$, jak i posługe „przepowiadania” (diakonía tou lógon: Dz 6,4), którą Apostołowie uważali za szczególne zadanie związane z ich misją. To, zdaniem większości egzegetów i teologów, oznacza, że dla św. Łukasza, owi, cieszący się dobrą sławą mężowie w liczbie siedmiu, których imiona są także wspomniane, nie utożsamiają się z tymi, którzy później będą prawdziwymi i właściwymi „diakonami”, stanowiącymi urząd służebny w Kościele ${ }^{8}$.

Druga trudność wynika z faktu, iż działania podjęte przynajmniej przez dwóch z owych „siedmiu”, tj. Szczepana i Filipa, zdecydowanie wykraczają poza te wspomniane początkowo, dla których wykonania ustanowiono „siedmiu”. Szczepan i Filip jawią się bowiem bardziej jako głosiciele Słowa Bożego aniżeli spełniający dzieła miłosierdzia. Są oni w swym działaniu podobni bardziej do Apostołów, nawet jeśli są im podporządkowani, aniżeli do właściwych diakonów sług. Dominuje w tym względzie zwłaszcza Szczepan, jako głosiciel Słowa Bożego oraz „pełen łaski” i „Ducha Świętego” (por. Dz 7,8-55), sprawca „cudów i znaków [...] wśród ludu” (Dz 6,8). Uroczysta i długa mowa (por. Dz 7,2-53) wygłoszona przez Szczepana dowodzi nie tylko jego znajomości natchnionych pism, ale przede wszystkim jego zdolności interpretacji Biblii w perspektywie chrystologicznej.

8 Por. A. Wikenhauser, Die Apostelgeschichte, Regensburg 1961; G. Stählin, Die Apostelgeschichte, Göttingen 1977, s. 259-260; Commissione Teologica Internazionale, Il Diaconato: evoluzione e prospettive, Città del Vaticano 2003, s. 16. 
Święty Łukasz w Dziejach Apostolskich charakteryzuje w podobny sposób Filipa. Jest on ukazany jako głosiciel Słowa Bożego w Samarii oraz sprawca wielu cudów i znaków (por. Dz 8,5-13). Głosił Dobrą Nowinę urzędnikowi dworskiemu królowej etiopskiej Kandaki, którego w następstwie ochrzcił (por. Dz 8,26-40). W Cezarei Nadmorskiej, w której mieszkał wraz z czterema córkami - „dziewicami” i „prorokiniami” (por. Dz 21,8-9) - nazwany jest „ewangelistą” (por. Dz 21,8).

Dzieje Apostolskie nie wspominają bliżej o innych członkach grupy „siedmiu”. Relacja św. Łukasza o Szczepanie i Filipie wystarcza jednak, aby twierdzić, że ich rola była ogromnie ważna, a zakres działalności szerszy od zwykłej „obsługi” stołów.

\subsection{PRÓBA ROZWIĄZANIA PROBLEMU}

W tym miejscu należałoby odpowiedzieć na pytanie dotyczące braku harmonii w Łukaszowym przekazie. Proponuje się w tym względzie różne rozwiązania.

Według opinii niektórych egzegetów, fakt ten wskazuje na wykorzystanie różnych źródeł pisanych, których ostatni redaktor nie opracował w wystarczający sposób. I tak Rudolf Bultmann wyodrębnia źródło nazwane przez niego „antiocheńskim” w Dz 6,1-12; 7,54-8,4; 11,14-26; 12,25, podczas gdy mowa Szczepana (por. Dz 7,1-53) i opowiadanie o Filipie (por. Dz 8,5-40) nie byłyby na ich miejscu9. Settimo Cipriani uważa, że nie można negować wykorzystania przez św. Łukasza różnych „źródeł” pisanych, niełatwych do zidentyfikowania ${ }^{10}$. Trudno jednak przyjąć, by autor Dziejów Apostolskich nie dostrzegł pewnych rozbieżności i pozostawił je takimi: co więcej, wręcz je wyakcentował, czego przykładem może być mowa o Filipie przyjmującym św. Pawła w Cezarei Nadmorskiej, gdzie nazwał go „ewangelistą", a potem dodał, że był on jednym z „siedmiu” (por. Dz 21,8). Jest to znak ewidentny, że św. Łukasz nie widział żadnej

9 Por. R. Bultmann, Zur Frage nach den Quellen der Apostelgeschichte, Tübingen 1967, s. 412-423; por. także G. Schneider, Die Apostelgeschichte, s. 420-421.

10 Por. S. Cipriani, Sono davvero „diaconi” i „sette” di Atti 6, 3-6?, w: Il diaconato permanente, Napoli 1983, s. 230-231. 
sprzeczności pomiędzy funkcją wykonywaną przez Filipa w Cezarei, a tą odnoszącą się do „obsługi” stołów.

W tym świetle nasuwa się konieczność drugiego wyjaśnienia, które, biorąc pod uwagę dynamikę narracji Łukaszowej, wydobywa z niej głębokie treści teologiczne, zakorzenione w rzeczywistości dokonujących się wydarzeń.

Święty Łukasz pisze: „Wówczas, gdy liczba uczniów wzrastała, zaczęli helleniści szemrać przeciwko Hebrajczykom, że przy codziennym rozdawaniu jałmużny zaniedbywano ich wdowy. «Nie jest rzeczą słuszną, abyśmy zaniedbali słowo Boże, a obsługiwali stoły» powiedziało Dwunastu, zwoławszy wszystkich uczniów" (Dz 6,1-2).

Motywem determinującym reakcję Apostołów jest więc „wzrost” liczebny wspólnoty, który sprawia i rodzi także trudności we wzajemnych relacjach jej członków.

Należy zauważyć, iż w cytowanym fragmencie Dziejów św. Łukasz po raz pierwszy wspomina o grupie „hellenistów”. Według opinii egzegetów, „helleniści” byli Żydami z diaspory, mówiącymi po grecku. Święty Łukasz przypomina, iż już w dniu Pięćdziesiątnicy w Jerozolimie przebywali „pobożni Żydzi ze wszystkich narodów pod słońcem” (Dz 2,5). $\mathrm{Z}$ upływem zaś czasu wielu z nich stało się chrześcijanami, ubogacając wspólnotę swym doświadczeniem religijnym i bardziej uniwersalistycznym spojrzeniem na rodzące się chrześcijaństwo. Tezę tę potwierdzałaby mowa Szczepana, kończąca się wezwaniem do wyjścia poza kult związany ze świątynią w Jerozolimie (por. Dz 7,44-50).

Jest więc rzeczą oczywistą, że taka mentalność „hellenistów” była sprzeczna $\mathrm{z}$ bardziej radykalnymi perspektywami innych chrześcijan pochodzenia żydowskiego. Fakt, iż miały być zaniedbywane wdowy „hellenistów” przy „codziennym rozdawaniu jałmużny” (Dz 6,2), stanowi jedynie dostrzegany przez historyka, zewnętrzny przejaw wewnętrznego konfliktu mentalności, który nie ułatwiał relacji pomiędzy obiema grupami tworzącymi jeden Kościół w Jerozolimie.

\section{3. "SIEDMIU" JAKO ODPOWIEDZIALNYCH ZA GRUPĘ „HELLENISTÓW"}

Jeśli taka była sytuacja, można sądzić, że rozwiązanie zaproponowane przez samych Apostołów nie miało jedynie zaradzić powstałym zanie- 
dbaniom w świadczeniu dobroczynności i sprawiedliwości w stosunku do wdów „hellenistów”, ale chciało wyjść naprzeciw sednu kwestii, tj. uznać słuszność żądań i perspektyw teologicznych „hellenistów”, proponując im „odpowiedzialnych”, którzy przez fakt, iż pochodziliby z ich szeregów, znaliby lepiej ich oczekiwania. Dla grupy „siedmiu” było to udzielenie przez Apostołów pełnomocnictw do wykorzystania w zależności od różnych potrzeb wspólnoty. „Włożenie rąk” zaś przez Apostołów podkreśla ich związek i zależność od grona Dwunastu. Stąd nie rodzi się Kościół „hellenistów”, lecz przygotowuje się strukturę organiczną dla grupy hellenistycznej jedynego Kościoła ${ }^{11}$.

„Obsługa stołów” jest tylko znakiem i początkiem wszechstronnej posługi wobec grupy „hellenistów” na łonie Kościoła, w perspektywie różnych potrzeb, które z czasem miały się pojawiać. W tym świetle łatwiej jest zrozumieć wieloraką aktywność Szczepana i Filipa. Działalność ta nie jest przejawem bezprawnego przywłaszczenia sobie przez nich władzy ani tym bardziej nie jest ona oznaką zaniedbania ze strony św. Łukasza przy komponowaniu w jedną całość różnych źródeł i tradycji, ale podyktowana jest raczej wyraźnym wytyczeniem wszystkich zadań, które na początku trudno było szczegółowo przewidzieć. „Siedmiu”, oddelegowanych do „obsługiwania stołów”, stało się w rzeczywistości odpowiedzialnymi za grupę „hellenistów”, która szybko uwidacznia się jako bardzo aktywna w pierwotnej wspólnocie chrześcijańskiej. Istotnie, ich dynamika misyjna jest przede wszystkim związana z głoszeniem Ewangelii poza granicami świata żydowskiego, najpierw w Samarii, później nawet wśród pogan.

Prześladowanie, które wybuchło w związku ze śmiercią Szczepana i dotknęło tylko „hellenistów” (por. Dz 8,2), sprawiło, że oni „rozproszyli się i głosili w drodze słowo” (por. Dz 8,4). Filip „ewangelizował” w Samarii i czynił to z tak wielką skutecznością, że z Jerozolimy udali się tam Piotr i Jan, aby się o tym naocznie przekonać i „włożyć ręce” na licznych ochrzczonych (por. Dz 8,5-25). Fakt ten zainteresował Kościół jerozolimski, ponieważ była to pierwsza próba ewangelizacji poza środowiskiem żydowskim. Samaria stanowiła swoisty pomost prowadzący do świata pogan. Rzeczywiście, niedługo później św. Łukasz dostrzeże, że to

${ }^{11}$ Por. S. Ciprani, Sono davvero "diaconi” i „sette” di Atti 6, 3-6?, s. 231; R. Fabris, Atti degli Apostoli, Roma 1977, s. 201-206. 
właśnie niektórzy z grupy „hellenistów” odważyli się jako pierwsi głosić Ewangelię Grekom: „Ci, których rozproszyło prześladowanie, jakie wybuchło z powodu Szczepana, dotarli aż do Fenicji, na Cypr i do Antiochii, głosząc słowo samym tylko Żydom. Niektórzy z nich pochodzili z Cypru i z Cyreny. Oni to po przybyciu do Antiochii przemawiali też do Greków i opowiadali Dobrą Nowinę o Panu Jezusie. A ręka Pańska była z nimi, bo wielka liczba uwierzyła i nawróciła się do Pana" (Dz 11,19-21). W tym przypadku interweniuje również Kościół jerozolimski, posyłając Barnabę, „człowieka dobrego i pełnego Ducha Świętego i wiary” (Dz 11,24), do oceny zaistniałej „nowej” sytuacji. Reakcja i obecność Barnaby podkreśla dobitnie nie tylko doniosłość i delikatność sprawy, ale przede wszystkim łączność różnych wspólnot z Kościołem Matką.

Praktycznie to „helleniści” stanowili tych, którzy pierwsi głosili Ewangelię poganom. W ten sposób przygotowali pole do przyszłej działalności misyjnej św. Pawła w świecie pogańskim i przewyższali rozmiarem pierwszą, nieśmiałą próbę św. Piotra, tj. wprowadzenie do Kościoła setnika Korneliusza (por. Dz 10,2).

W świetle powyższych analiz łatwo uświadomić sobie doniosłość, jaką przypisywał św. Łukasz jedynie pozornie małemu sporowi pomiędzy Żydami i „hellenistami” odnośnie do opieki nad wdowami, który przyczynił się do wyboru „siedmiu” pierwszych „współpracowników” Apostołów.

Dla św. Łukasza problem ten był szczególnie ważny z dwóch względów:

a) Jest to pierwszy przypadek „rozdziału władzy apostolskiej” i „udzielenia pełnomocnictw” również innym członkom wspólnoty, w zależności od określonych celów i potrzeb, z otwarciem się jednak na możliwość dostosowania do przyszłych sytuacji. Współpracownicy ci, rozpoczynając swoją działalność od obsługi stołów, staną się później głosicielami Ewangelii, odważnymi misjonarzami, szafarzami sakramentów, sprawcami cudów, zawsze jednak, co należy podkreślić, będą podporządkowani Apostołom.

b) Historyczny wybór „siedmiu” stał się decydujący dla rozwoju wczesnego chrześcijaństwa i jego otwarcia na pogan. Stąd rozdziały Dz 6-15, kończące się wzmianką o tzw. soborze jerozolimskim i wydaniu po jego zakończeniu dekretu otwierającego 
drogę głoszenia Słowa Bożego poganom, noszą piętno ustanowienia „siedmiu”, dokonanego z pewnością z inspiracji Bożej przez Apostołów.

\subsection{DIAKONIA W 112 LIŚCIE ŚW. PAWŁA DO KORYNTIAN}

Święty Paweł posługuje się terminologią dotyczącą diakonatu najczęściej w 1 i 2 Liście do Koryntian. Rzeczownik diakonía występuje w obu pismach 14 razy, diákonos użyty jest 6 razy, a forma czasownikowa diakonein 2 razy $^{12}$.

Apostoł Narodów, posługując się terminem diakonía, ma na myśli naturę i cechy charakterystyczne „urzędu kościelnego”. Inspiracją do tej refleksji Pawła były okoliczności jego życia, a zwłaszcza niełatwe stosunki z chrześcijanami Koryntu.

Roman Penna ${ }^{13}$ podkreśla, że wspomniana terminologia $\mathrm{w} 1$ i 2 Liście do Koryntian nie posiada znaczenia ściśle hierarchicznego, które sukcesywnie przypisywane będzie diakonatowi w życiu i w strukturze Kościoła. W Listach tych zachowuje ona zasadniczo swoją pierwotną i ogólną semantykę „służby”, choć Paweł nie używa jej jedynie w kontekście eklezjalno-wspólnotowym. Według św. Pawła diakonía jest realizowana na różne sposoby i na różnych stopniach.

Apostoł ukazuje przede wszystkim posługe „diakońską”, do której wykonywania powołana jest cała wspólnota chrześcijańska. Jest to zbieranie kolekt na rzecz chrześcijan, mieszkających w Jerozolimie. O ich początkach oraz znaczeniu kościelnym i socjologicznym jest mowa w Ga 2,10; Rz 15,26; 2 Kor 8,13-14. W 2 Liście do Koryntian św. Paweł kilkakrotnie posługuje się rzeczownikiem diakonía na określenie tego typu zaangażowania chrześcijańskiego. W rozdziale 8 pisze: „Donosimy wam, bracia, o łasce Bożej, jakiej dostąpiły Kościoły Macedonii, jak to w dotkliwej próbie ucisku uradowały się bardzo i jak skrajne ich ubóstwo zajaśniało bogactwem prostoty.

${ }_{12}$ Por. R. Morgenthaler, Statistik des neutestamentlichen Wortschatzes, Zürich $1992^{2}$, s. 87.

${ }^{13}$ Por. R. Penna, La diaconia nelle lettere ai Corinzi, w: Il diaconato permanente, s. 211. 
Według możliwości, a nawet - zaświadczam to - ponad swe możliwości okazały godność, nalegając na nas bardzo i prosząc o łaskę współdziałania w posłudze na rzecz świętych” (2 Kor 8,1-4). Podobnie do posługi tej nawiązuje Apostoł Narodów w rozdziale 9: „O posłudze zaś, którą się pełni dla świętych, nie potrzebuję wam pisać” (2 Kor 9,1). Należy podkreślić, że Paweł przypisuje tego typu diakonii głębokie znaczenie teologiczne. Nazywa ją „łaską”. Co więcej, nadaje jej wymiar liturgiczny: „Posługiwanie bowiem tej sprawie społecznej nie tylko uzupełnia to, na co nie stać świętych, lecz obfituje w liczne dziękczynienia składane Bogu" (2 Kor 9,12). Staje się ona według Apostoła aktem kultu: „Ci, którzy oddają się tej posłudze, wielbią Boga za to, żeście posłuszni w wyznawaniu Ewangelii Chrystusa, a w prostocie stanowicie jedno z nimi i ze wszystkimi” (2 Kor 9,13). Dla Pawła jest to posługa zacieśniająca więzy wspólnotowe między Kościołami lokalnymi, stąd pragnie zaangażować w nią całą wspólnotę koryncką: „A podobnie jak obfitujecie we wszystko, w wiarę, w mowę, w wiedzę, we wszelką gorliwość, w miłość naszą do was, tak też abyście i w tę łaskę obfitowali” (2 Kor 8,7). Apostoł nie nakazuje wprost Koryntianom spełniać tej posługi, ale wskazuje na gorliwość innych i pragnie poddać próbie ich miłość: „Nie mówię tego, aby wam wydawać rozkazy, lecz aby wskazując na gorliwość innych, wypróbować waszą miłość” (2 Kor $8,8)$. Jego naleganie w tym względzie wskazuje jasno, że chodzi tu o ważną sprawę: „Tak więc udzielam wam rady, a to przyniesie pożytek wam, którzy zaczęliście już ubiegłego roku nie tylko chcieć, lecz i działać. Doprowadźcie teraz to dzieło do końca, aby czynne podzielenie się tym, co macie, potwierdzało waszą chętną gorliwość” (2 Kor 8,10-11); „Okażcie więc im wobec Kościołów waszą miłość i dowody naszej z was chluby!” (2 Kor 8,24); „Każdy niech przeto postąpi tak, jak mu nakazuje jego własne serce, nie żałując i nie czując się przymuszonym, albowiem radosnego dawcę miłuje Bóg" (2 Kor 9,7). Każdy członek wspólnoty jest wezwany do wykonywania diakonii miłości, będącej najbardziej zasadniczą, wymagającą i jednocześnie najbardziej typową formą tożsamości chrześcijańskiej ${ }^{14}$.

${ }^{14}$ Por. tamże; Ch. Pierrot, Ministri e ministeri. Indagine nelle comunità cristiane del Nuovo Testamento, Cinisello Balsamo 2002, s. 245-246; F. Lang, Le lettere ai Corinzi, Brescia 2004, s. 307-308 i 394-405; L. Bassetti, La dimensione umana della formazione diaconale, „Seminarium” 48 (2008) 4, s. 824-825. 
Należy zauważyć, iż diakonia, o której mowa, obejmuje też niesienie pomocy materialnej najbardziej potrzebującym: „Teraz więc niech wasz dostatek przyjdzie z pomocą ich potrzebom, aby ich bogactwo było wam pomocą $\mathrm{w}$ waszych niedostatkach i aby nastała równość według tego, co jest napisane: Nie miał za wiele ten, kto miał dużo. Nie miał za mało ten, kto miał niewiele" (2 Kor 8,14). Aspekt ten przypomina nie tylko znaczenie pierwotne słowa greckiego diakonía, ale przede wszystkim zadanie codziennego rozdzielania rzeczy niezbędnych wdowom chrześcijan pochodzenia hellenistycznego, powierzone według Dziejów Apostolskich siedmiu wybranym mężom (por. Dz 6,1 i n.). Istnieje jednak zasadnicza różnica. To, co było wcześniej zarezerwowane jako specyficzne zadanie wykonywane przez niektórych mężczyzn wybranych ad hoc, teraz jest ukazane, co więcej, wymagane jako zaangażowanie wspólnotowe. W tym znaczeniu występuje diakonia, do wykonywania której powołany jest każdy ochrzczony. Diakonia ta nie jest przejawem filantropii, ale wypełnieniem zobowiązań wynikających z przyjętego sakramentu Chrztu i wyznawanej wiary (por. 2 Kor 9,13-14) ${ }^{15}$.

Święty Paweł wskazuje również na drugi stopień „diakonii”, który bardziej przybliża „posługę” chrześcijańską do działania urzędowego w sensie strukturalnym. W 1 Liście do Koryntian pisze: „różne [...] są rodzaje posługiwania (diakonión), ale jeden Pan” (1 Kor 12,5). Występujący w tekście rzeczownik diakonión wydaje się mieć znaczenie ściśle sprecyzowane oraz ogólne, tj. w odniesieniu do różnych posług kościelnych, jak wskazuje na to kontekst bezpośredni: „Różne są dary łaski, lecz ten sam Duch” (1 Kor 12,4); „różne są [...] działania, lecz ten sam Bóg, sprawca wszystkiego we wszystkich” (1 Kor 12,6). Występując zaś w paralelizmie synonimycznym z „charyzmatami” oraz „działaniami”, służy do ukazania ich wymiaru diakońskiego „dla wspólnego dobra” (1 Kor 12,7). Innymi słowy, każdy urząd wykonywany w Kościele jest dosłownie „diakonatem”, a raczej „diakonią, czyli posługą. Zatem nie istnieje w Kościele urząd, który nie byłby rozumiany w sensie posługi. „Służenie” należy rozumieć niemal za cechę charakterystyczną urzędu. Angażowanie się na rzecz wspólnoty chrześcijańskiej oznacza wykonywanie jakiejś diakonii.

15 Por. R. Penna, La diaconia nelle lettere ai Corinzi, s. 213. 
O takim znaczeniu myśli św. Paweł, kiedy pisze: „Napominam was, bracia: znacie dom Stefanasa jako ten, który stanowi pierwociny Achai i który się poświęcił na służbę świętym” (1 Kor 16,15). Apostoł już w 1 Kor 1,16 mówił: „ochrzciłem dom Stefanasa” w Koryncie. Należy w tym miejscu wyjaśnić, że termin „dom”, greckie oikía, wskazuje w znaczeniu podstawowym, zarówno na osoby złączone tym samym węzłem krwi, jak i te, które bezpośrednio je otaczają, przede wszystkim sługi. Według świadectwa Apostoła wszyscy oni wzięli na siebie odpowiedzialność „służby świętym”. Oznacza to, że nie zmarnowali łaski Chrztu, ale ją wykorzystali w hojnym i wiarygodnym zaangażowaniu kościelnym. Stąd św. Paweł, kontynuując swoją myśl, pisze: „żebyście takim zawsze byli posłuszni, podobnie jak każdemu, kto współpracuje i trudzi się z wami” (1 Kor 16,16). Diakonia spełniana przez „dom” Stefanasa, choć nie opisano, na czym szczegółowo polegała, musiała dotyczyć w jakiejś mierze życia wspólnotowego chrześcijan korynckich, tworząc pośród nich niemal zarodek struktury. Nie można wykluczyć, iż diakonię tę należy rozumieć w kontekście organizowanej kolekty dla „świętych” (por. 1 Kor 16,1). Jednakże i w takim przypadku zalecenie św. Pawła, wzywające Koryntian do podporządkowania się, nie traci nic na swoim znaczeniu i pozostaje wystarczająco znamienne, jeśli chodzi o odpowiedzialność „domu” Stefanasa i jego autorytet ${ }^{16}$.

Analiza 1 i 2 Listu do Koryntian wskazuje wyraźnie, że diakonia jest posługą wobec drugiego człowieka tak bardzo znaczącą i zaszczytną, iż należy uznać, że nie pochodzi ona od człowieka, ale ma źródło w Bogu. Diákonoí są w istocie „oddani posługiwaniu zleconemu im przez miłosierdzie" (2 Kor 4,1). Dlatego też nie mogą dawać nikomu sposobności do zgorszenia, aby nie pogardzono ich posługą (por. 2 Kor 6,3). Bezinteresowność stanowi najwyższą regułę odpowiedzialnego diakonatu: „Aby wam przyjść z pomocą [...] nikomu nie okazałem się ciężarem” (2 Kor 11,8-9). Co więcej, jest zasadniczo aktem wspaniałomyślności konkretnej osoby.

\section{DZIEŁA MIŁOSIERDZIA DIAKONÓW W KOŚCIELE STAROŻYTNYM}

Od początku dziejów Kościoła dzieła miłosierdzia, diecezjalne czy parafialne, których wykonywanie należy do obowiązków bisku-

16 Por. tamże, s. 241-215. 
pów i prezbiterów, są przez nich powierzane w sposób szczególny diakonom $^{17}$.

W epoce ojców apostolskich Kościoła zaświadczają o tym m.in.: Ignacy Antiocheński ${ }^{18}$ i Hermes ${ }^{19}$.

Dla Ignacego działalność charytatywna jest najbardziej specyficzną posługą diakonów we wspólnocie kościelnej ${ }^{20}$. Biskup antiocheński w $L i$ ście do Trallian o tej posłudze diakonów pisze: „Nie są bowiem usługującymi przy jedzeniu i piciu, lecz sługami Kościoła Bożego"21.

Jest to interpretacja misteryczna wskazań dotyczących posługi „siedmiu” (por. Dz 6,1 i n.). Troska o stoły nie jest priorytetową działalnością społeczną, lecz służbą Chrystusowi, który odczuwa głód, pragnienie, jest w potrzebie: „Wszystko, co uczyniliście jednemu z tych braci moich najmniejszych, Mnieście uczynili” (Mt 25,40). Diakonat jest więc przede wszystkim posługą Chrystusowi i Kościołowi Bożemu ${ }^{22}$. Zdaniem Ignacego posługa ta ma swój fundament w tajemnicy Chrystusa, który stał się Sługą wszystkich. On też stanowi dla diakonów źródło łaski i wzór do naśladowania ${ }^{23}$.

Innym ojcem apostolskim wspominającym posługę miłosierdzia diakonów jest Hermas, brat papieża Piusa I, którego pontyfikat przypadł

17 Por. R. Selejdak, Zarys historyczny diakonatu stałego, Częstochowa 1998, s. 2025; tenże, Diakonat stały w świetle Biblii i historii Kościoła, Częstochowa 2002, s. 58-88; M. Cancouét, B. Violle, I diaconi. Vocazione e missione, s. 74-77; N. Ceci, Il ministero del diacono nel mondo del lavoro, Roma 1999, s. 37; B. Fischer, Dienst und Spiritualität des Diakons, w: Frömmigkeit der Kirche. Gesammelte Studien zur christlichen Spiritualität, red. A. Gerhards, A. Hainz, Bonn 2000, s. 196; S. Sander, Gott begegnet im Anderen. Der Diakon und die Einheit des sakramentalen Amtes, Freiburg im Breisgau 2006, s. 166; M. Gawlik, M. Marczewski, Dyrektorium o posłudze i życiu diakonów stałych, „Roczniki Teologiczne" 46 (1999) 8, s. 205-210.

18 Por. Ignacy Antiocheński, Epistula ad Trallianos, 2, 3, PA, I, 244; Epistula ad Magnesios, 6, 1, PA I, 235.

19 Por. Hermes, Pastor, Podobieństwo IX, 26, 2, PA I, 621-632.

20 Por. E. Cattaneo, Evangelo, Chiesa e carità nei Padri, Roma 1995, s. 57.

${ }^{21}$ Ignacy Antiocheński, Epistula ad Trallianos, 2, 3, PA I, 244: tłum. pol. A. Świderkówna, Pierwsi świadkowie. Wybór najstarszych pism chrześcijańskich, w: Ojcowie żywi, t. 8, oprac. M. Starowieyski, Kraków 1988, s. 151.

22 Por. tenże, Epistula ad Smyrnenses, 7, 1, PA I, 285.

23 Por. R. Selejdak, Figura e ministero dei diaconi nelle Lettere di Ignazio d'Antiochia, „Vox Patrum” 26 (2006) 49, s. 591. 
na lata $140-155^{24}$. W dziele zatytułowanym Pasterz ukazuje on m.in. wspomnianą posługę diakonów wobec wdów i sierot. Autor, czyniąc odniesienie do koncepcji diakonatu realizowanej przez „siedmiu”, wyjaśnia, iż w Kościele posługa tajemnicom Chrystusa dokonuje się nieustannie poprzez posługę ubogim ${ }^{25}$

W pierwszej połowie III wieku Hipolit ukazuje diakonów jako gwarantów opieki i pomocy najbardziej potrzebującym, zwłaszcza w czasie klęski zarazy: „W czasie zarazy diakon winien szczególnie skrupulatnie donosić o chorych. Jeśli nie ma prezbitera, który by przyjmował i rozdzielał ofiary na wdowy i osoby chore, niech to czyni diakon, bacznie zwracając uwagę na tych, co roznoszą dary, iżby sumiennie wypełniali swą funkcję i rozdawali eulogie"26.

Bardzo ważnym świadectwem o posłudze charytatywnej diakonów w Kościele pierwotnym są Didascalia Apostolorum ${ }^{27}$. Dzieło to zostało napisane w języku greckim przez nieznanego autora w Syrii ${ }^{28}$. Fakt, iż w bardzo wielu miejscach Didascalia Apostolorum ukazują diakonów jako głównych wykonawców dzieł miłosierdzia, spowodował, że wielu autorów uważa tamten czas za okres wyjątkowego splendoru diakonatu ${ }^{29}$.

${ }^{24}$ Por. F. Drączkowski, Patrologia, Pelplin-Lublin, 1998, s. 45-48; H.R. Drobner, Patrologia, Casale Monferrato 1998, s. 92-95; J. Quasten, Patrologia, t. 1, Casale Monferrato $1975^{3}$, s. $89-93$.

25 Por. S. Zardoni, I diaconi nella Chiesa. Ricerca storica e teologica sul diaconato, Bologna $1991^{2}$, s. 27; R. Selejdak, Diakonat stały w świetle Biblii i historii Kościoła, s. 50.

${ }^{26}$ Hipolit Rzymski, La Tradition Apostolique, Sources chrètiennes, wyd. H. de Lubac, J. Daniélou, Paris 1941 (dalej: SCh) 11 bis, 98: tłum. własne.

27 Por. Didascalia et Constitutiones Apostolorum, t. 1, wyd. F.X. Funk, Paderbornae 1906 (dalej: DCA), Prolegomena, s. IV-V; A. M. Stickler, Historia iuris canonici latini, t. , Torino 1950, s. 24-25; F. Nau, La Didascalie des Douze Apôtres, Paris 1912, s. XX, n. 2; J.G. Ayesta, Alcuni aspetti del servizio alla carità nella „Tradizione Apostolica” e nella „Didascalia dei Dodici Apostoli”, w: Diritto canonico e servizio della carità, red. J. Miñambres, Varese 2008, s. 443.

${ }_{28}$ Por. H. R. Drobner, Patrologia, s. 609-611; J. Quasten, Patrologia, s. 407.

${ }_{29}$ Por. A. G. Hammann, Vie liturgique et vie sociale: repas des pauvres. Diaconie et diaconat. Agape et repas de charité. Offrande dans lantiquité chrétienne, Paris 1968, s. 111: „A l'époque de la Didascalie, le diaconat semble avoir atteint sa pleine maturité et s'être déployé en action sociale, au service de la communauté”; J. Colson, La fonction diaconale aux origines de l'Église, Paris-Brügge 1962, s. 112: „Ces textes de la Didascalie 
Według Didascalia Apostolorum diakoni, posługując ubogim, naśladują posługę, którą wykonywał Chrystus: „Jak nasz Zbawiciel i Mistrz rzekł w Ewangelii: «Lecz kto by między wami chciał się stać wielkim, niech będzie waszym sługą. A kto by chciał być pierwszym między wami, niech będzie niewolnikiem waszym, na wzór Syna Człowieczego, który nie przyszedł, aby Mu służono, lecz aby służyć i dać swoje życie na okup za wielu» (Mt 20,26-28); wy, diakoni, musicie czynić to samo, nawet jeśli wiąże się to z oddaniem życia za braci, w służbie do wykonywania której jesteście przeznaczeni. Jeśli więc Pan nieba i ziemi wykonuje posługę, która jest naszą, o ile bardziej my musimy to czynić dla naszych braci, ażeby być jak Chrystus, Jego naśladowcami i sługami”"30.

Diakoni realizują posługę charytatywną nie tylko poprzez informowanie biskupa o osobach potrzebujących pomocy materialnej ${ }^{31}$, tak jak zaleca to Tradycja apostolska, ale są tymi, za pośrednictwem których wierni przekazują ofiary dla potrzebujących ${ }^{32}$, którzy sami zbierają datki na ubogich ${ }^{33}$, odwiedzają, pomagają, umywają nogi chorym, w podeszłym wieku, kalekom ${ }^{34}$, cierpiącym z powodu wyznawania wiary w Chrystusa ${ }^{35}$, opiekują się sierotami i wdowami ${ }^{36}$. O każdym ciepiącym mieli informować biskupa. Wszystkie działania charytatywne winni wykonywać oni w łączności z biskupem i być jemu całkowicie posłuszni ${ }^{37}$. Od diakonów zatem w głównej mierze zależy cała organizacja działalności charytatywnej Kościoła ${ }^{38}$.

des Apôtres se passent de commentaire. Ils nous montrent le nous apprendront plus grand-chose de neuf sur cette function".

${ }^{30}$ Didascalia Apostolorum, III, 13, DCA I, 214: tłum. własne.

31 Por. tamże, II, 31, DCA I, 112.

32 Por. tamże, II, 25, DCA I, 92-101.

33 Por. tamże, II, 27, DCA I, 106.

${ }^{34}$ Por. tamże, III, 13, DCA I, 212-213,

${ }_{35}$ Por. tamże, V, 1, DCA I, 236.

36 Por. tamże.

37 Por. tamże, III, 13, DCA I, 216.

38 Por. S. Zardoni, I diaconi nella Chiesa, s. 35; A. Abreu, O Diaconado Permanente ao longo de História: da emergéncia ao desaparecimento, Humanistica e Teologia 29 (2008) 2, 44-45; G. Ayesta, Alcuni aspetti del servizio alla carità nella „Tradizione Apostolica” e nella „Didascalia dei Dodici Apostoli", s. 447-454. 
Didascalia Apostolorum, ukazując ogromną rolę diakonów w dystrybucji darów materialnych najbardziej potrzebującym, przestrzegają ich przed niebezpieczeństwem chciwości. Stąd np. w momencie ustanawiania diakonów wzywa się ich do naśladowania biskupów i do intensywnej posługi bez szukania niedozwolonych zarobków ${ }^{39}$. Ponadto autor Didascaliów w części poświęconej upominaniu wiernych przestrzega biskupów i diakonów, aby nie wykonywali swoich obowiązków tylko ze względu na ewentualne korzyści materialne ${ }^{40}$.

W tym kontekście warto też podkreślić, iż Didascalia Apostolorum uwrażliwiają biskupów i diakonów, aby zwracali uwagę na pochodzenie dóbr materialnych składanych jako pomoc dla potrzebujących. Między innymi zabraniają przyjmowania ofiar od producentów bożków, zabójców, lichwiarzy itp. ${ }^{41}$ Wskazania te miały uzasadnienie głęboko religijne. Didascalia przypominają bowiem biskupom i diakonom, iż sieroty i wdowy były niejako Bożymi ołtarzami, stąd złożone dla nich ofiary powinny być uważane za składane samemu Bogu ${ }^{42}$. Według autora Didascaliów cel nawet tak dobry i godny pochwały nie usprawiedliwiał wykorzystywania dla jego osiągnięcia niedozwolonych środków ${ }^{43}$.

Pragnąc zapobiec przekształceniu posługi charytatywnej diakonów w jakąś formę opieki społecznej, autor Didascalia Apostolorum kładzie duży nacisk na przestrzeganie zasady misteryjno-ascetycznej, według której diakoni są wezwani do tego, aby swoją diakonię interpretowali na wzór posługi Chrystusa diakona-sługi ${ }^{44}$.

Według Cypriana diakoni zajmują się administracją kasy kościelnej i poświęcają głównie działalności charytatywnej ${ }^{45}$.

Również Kanony apostolskie ukazują diakonów jako tych, którzy pomagają biskupowi i kapłanom przede wszystkim poprzez niesienie pomocy materialnej wszystkim potrzebującym. Swoje zadania diakoni

39 Por. Didascalia Apostolorum, III, 13, DCA I, 212.

40 Por. tamże, II, 17, DCA I, 62.

41 Por. tamże, IV, 6, DCA I, 224-226.

${ }^{42}$ Por. tamże, IV, 5, DCA I, 222-224.

43 Por. tamże, IV, 8, DCA I, 228.

${ }^{44}$ Por. G. Sander, Gott begegnet im Anderen, s. 164-165.

45 Por. Cyprian, Epistula 43, 1, 1, w: Corpus Christianorum. Series Latina, Turnhout 1953 (dalej: CCL), III B, 200; Epistula 52, 1, 2, CCL III B, 243-244. 
spełniają niezależnie od uwarunkowań czasu i miejsca oraz bez względu na stan osoby potrzebującej. Zakres posług diakońskich jest ściśle określony i nikt nieposiadający godności diakońskiej nie mógł ich wykonywać w imieniu wspólnoty kościelnej ${ }^{46}$.

Diakoni, wypełniając posługę charytatywną, byli odpowiedzialni za prowadzenie dokumentacji dotyczącej chorych i potrzebujących, szczególnie zaś tych, do których winien udawać się biskup osobiście ${ }^{47}$. Winni oni również informować biskupa o potrzebach wiernych ${ }^{48}$ oraz rozdzielać jałmużnę $e^{49}$.

Posługę miłosierdzia spełnianą przez diakonów w pierwszych wiekach chrześcijaństwa przypomina też syryjski Liber graduum. Dzieło to powstało między 303 a 324 rokiem. Na datę tę zdają się wskazywać wzmianki, nawiązujące do prześladowań Dioklecjana i śmierci Licyniusza. Środowisko zaś, w którym powstało, było prawdopodobnie związane ze szkołą w Edessie, w której pod koniec IV wieku wystąpiły wyraźne wpływy nestorianizmu.

Liber graduum zalicza diakonów do tzw. klasy sprawiedliwych. Przynależący do tej klasy nie otrzymywali pełnego chrztu w Duchu i nie płonął w nich ogień Boży. Swe życie poświęcali czynnej miłości bliźniego, okazywanej w sposób praktyczny. Utrzymywali oni przede wszystkim ludzi przynależących do tzw. klasy doskonałych, którzy naznaczeni Duchem, całkowicie odrzucali życie doczesne, nie pracowali, nie zarabiali na swe życie, nie wspierali materialnie ubogich, nie pełnili żadnych funkcji w Kościele, ale oddawali się jedynie modlitwie i dawaniu świadectwa apostolskiego ${ }^{50}$. Ponadto sprawiedliwi, a wśród nich diakoni zajmowali się chorymi, nagimi, przybyszami i wszystkimi potrzebującymi doczesnej pomocy. Poza zakresem działalności diakonów pozostaje funkcja przewodników duchowych i przekazicieli świadectwa, naznaczonych Duchem Pocieszycielem, przysługująca wyłącz-

46 Por. Les 127 Canons des Apôtres, I, kan. 58, w: Patrologia Orientalis, R. Graffin, F. Nau, Paris 1903 (dalej : POr), 8, 642-643.

47 Por. tamże, I, kan. 41, POr 8, 613.

${ }^{48}$ Por. tamże, I, kan. 23, POr 8, 592.

49 Por. tamże, I, kan. 17, POr 8, 587.

${ }^{50}$ Por. K. Klauza, Syryjski „Liber graduum” jako źródło do teologii diakonatu IV-V wieku, „Vox Patrum” 9 (1989) 17, s. 683-684. 
nie doskonałym. Diakoni stoją bliżej bliźnich i z tytułu swej posługi są narażeni na krytykę ze strony tych, którym służą. Liber graduum pragnie w tym względzie bronić doskonałych od takiego niebezpieczeństwa, gdyż mogłoby ono zafałszować siłę ich świadectwa ${ }^{51}$.

\section{POSŁUGA MIŁOSIERDZIA DIAKONÓW STAŁYCH W CZASACH WSPÓŁCZESNYCH}

Diakoni przestają pełnić dzieła miłosierdzia w średniowieczu, kiedy to diakonat staje się jedynie stopniem do kapłaństwa, a jego nieliczne funkcje mają charakter liturgiczny i administracyjny ${ }^{52}$.

Po przywróceniu diakonatu stałego przez Sobór Watykański II posługiwanie dziełom miłosierdzia stało się znowu pierwszorzędnym

${ }^{51}$ Sermo 3, 7, w: Liber graduum e codicibus syriacis Parisiis, Londini, Romae, Hierosolymis, wyd. M. Kmosko, Parisiis 1926, 3, 58-59: „Debuisset enim [perfectus] dominos divitiarum docere, ut ipsi, suismet minibus benefacerent ex opibus suis cuique indigenti et afflicto, sicut dixit Apostolus: «Divites, qui in hoc mundo sunt, doce paratos esse ad opera bona et thesaurizare sibi thesauros in caelo, nec ponere fiduciam in divitiis cauducis» (1 Tm 6,17-18). Sic igitur debuisset facere ei, qui in cura dandi et accipiendi iacet: docere divitiarum possessores ut ex his, quae possident, ipsi suismet minibus darent pauperibus, et ipsum assiduum esse in oratione et deprecatione et ministerio et lectione et in verbo Dei et promptum paratumque (succurrere) cuique indigenti doctrina et verbo veritatis Domini, sicut psie Dominus et Apostoli similiter fecerunt constituentes diaconos aegrotis et nudis et peregrinis et captivis et omnibus egenis, ut ipsi verbum Dei et orationem administrarent. Similiter is, qui tollit crucem et accepto paraclito perfectus fit, nullum prorsus habet consortium cum rebus visibilibus; si vero illa diligat, fit iustus, non perfectus, quia non renuntiavit visibilibus. Si autem non videant hi divites, ubi afflictus sit, ostendens ostendat eis tantum, ubi sint egeni, tantum absit, ut ipse in donum suam (eleemosynas) recipiat et in tribulationem maximam incidat, nam murmurabunt in eum plurimi, axacerbabunt spiritum eius, nec eum perfici sinent, cum is, cui provisum est, gaudeat et is, quem sibi alere non erat copia accuset eum murmurando, quod acceperit, nec nobis dederit, et ipsum, rebus visibilibus approximantem malum reddunt, nisi dator perfectus se a divitiis exinanierit et curam habuerit eorum, qui carent scientia Domini, omniumque hominum, ut salvi fiant perfectique, fiatque assiduus in oratione et supplicatione et ministerio verbi Dei apud omnes, et pro seipso, qua ranione omnibus sibique benefaciet oratione et adhortatione salutis novae".

52 Por. G. Hammann, Storia del diaconato. Dal cristianesimo delle origini ai riformatori protestanti del XVI secolo, Magnano 2004, s. 159. 
zadaniem diakonów stałych. Na mocy przyjętego sakramentu święceń, razem $\mathrm{z}$ biskupem i prezbiterami diecezji uczestniczą oni również $\mathrm{w}$ tych samych funkcjach pasterskich ${ }^{53}$. Funkcje te jednak wykonują w sposób odmienny, służąc i pomagając biskupowi i prezbiterom. Udział diakonów w funkcjach pasterskich powoduje, iż służą ludowi Bożemu w imię Chrystusa. Stąd diakoni są wezwani do wykonywania ich w duchu pokornego miłosierdzia, zgodnie ze słowami św. Polikarpa ze Smyrny, który mówi, że powinni być „czyści pod każdym względem, pełni współczucia, gorliwi, żyjący według prawdy naszego Pana, który stał się sługą wszystkich" ${ }^{54}$.

Zadaniem diakonów w łączności hierarchicznej z biskupem oraz prezbiterami, tak jak wymaga tego sama jedność konsekracji i misji, jest posługa miłosierdzia ${ }^{55}$, a także zachęcanie całej wspólnoty Kościoła lokalnego do współuczestnictwa w tym dziele, z uwzględnieniem charyzmatów ubogacających życie i misję Kościoła ${ }^{56}$. Ta właśnie posługa

53 Por. Kodeks Prawa Kanonicznego (dalej KPK), kan. 129 \$ 1; DPŻDS, n. 37.

${ }^{54}$ Polikarp ze Smyrny, Epistula ad Philippenses, V, 1-2, PA I, 301-303; tłum. pol. A. Świderkówna, Pierwsi świadkowie, s. 194; por. H. Renard, Diaconat et service de la charité, w: Diaconat XXI siècle, red. A. Haquin, Ph. Weber, Bruxelles-Paris-Montréal 1997, s. 117-130.

${ }_{55}$ Por. Paweł VI, Motu proprio Sacrum diaconatus ordinem, 18.06.1967, V, 22, 9, AAS 59 (1967) 702; Jan Paweł II, Discorso ai diaconi permanenti in Italia, 16.03.1985, n. 1, w: Insegnamenti 8 (1985) 1, s. 648-649; tenże, Discorso ai diaconi permanenti di Detroit, 10.09.1987, n. 4, w: Insegnamenti 10 (1987) 3, s. 657-658; DPŻDS, n. 37; J. J. McCarthy, The "Diaconia” of Charity in the Permanent Diaconate: its Application to certain Clerical Offices as addressed in the "Directory for the Ministry and Life of Permanent Deacons", Romae 2000, s. 146-158; H. M. Legrand, Le diaconat dans sa relation à la théologie de l'Église et aux ministères. Rèception et devenir du diaconat depuis Vatican II, w: Diaconat XXI siècle. Actes du colloque de Louvain-la-Neuve (11-15 septembre 1994), red. A. Haquin-Ph.Weber, Bruxelles-Paris-Montrèal 1997, s. 5; T. Rincón-Pérez, El orden de los clérigos o ministros sagrados, Pamplona 2009, s. 348.

56 A. Lorscheider, Desaflos y Perspectivas del Diaconado en una Iglesia toda Ministerial, „Seminarios” 152 (1999), s. 101: „El diácono, es un consagrado para el servicio. Es un comprometido a servir, y a invitar a todos a servir. El diácono, desarrollando su actividad en el campo de la palabra de Dios, de la Eucaristia y de las obras de misericordia, está llamado a promover las ocasiones de enccuentros,de diálogos, de comunión [...]. El carisma especifico del diácono es suscitar los diversos ministerios en la comunidad y el espiritu de servicio en todos los ministerios"; por. także, DPŻDS, n. 37; A. Altana, Lattuazione del diaconato nella Chiesa italiana, RSR 6 (1992) 1, s. 178-179; J. Durán y Durán, Das Amt des Diakons im Dokument von Aparecida 2007, „Diaconia XP” 
jest najbardziej typową dla diakonów ${ }^{57}$. Powinna też być najważniejsza. Oddziałuje w sposób niezwykle istotny na posługę liturgiczną i słowa ${ }^{58}$. Posługa miłosierdzia najlepiej wyraża w sposób widzialny tożsamość diakonów i ich upodobnienie do Chrystusa Sługi ${ }^{59}$. Nie ulega wątpliwości, iż

43 (2008) 1-2, s. 90-91; S. Sander, Das Amt des Diakons. Eine Handreichung, Freiburg im Breisgau 2008, s. 72; V. Cenini, La Comunità del diaconato in Italia, „Orientamenti Pastorali" 3 (1988), s. 54.

57 Por. WDFDS, n. 9; H. Denis, R. Schaller, Il diaconato nel mondo d'oggi, Milano 1968, s. 46-48; A. Montan, Il servizio del diacono in una Chiesa ministeriale, „Orientamenti Pastorali" 7 (2005), s. 140-142; E. U. Kmiec, The Profile and the Discernment of Candidates for the Permanent Diaconate, „Seminarium” 37 (1997) 4, s. 767; Ph. Goyret, Chiamati, consacrati, inviati. Il sacramento dell'Ordine, Città del Vaticano 2003, s. 132; A. Borras, B. Pottier, La grazia del diaconato. Questioni attuali a proposito del diaconato latino, Assisi 2005, s. 35; E. Petrolino, Quale diaconato per quale città dell'uomo, „Il diaconato in Italia” 145-146 (2007), s. 13; M. Cancouét, B. Violle, I diaconi. Vocazione e missione, s. 74-78; N. Ceci, Il ministero del diacono nel mondo del lavoro, s. 100-102; C. Garzia, Dalla strada al tempio, „Il diaconato in Italia” 133 (2005), s. 35-36; D. Sigalini, Linee di impegno per il diaconato permanente in Italia. Conclusioni del seminario di studio, „Orientamenti Pastorali” 7 (2005), s. 204-205; G. Müller, Können Frauen die sakramentale Diakonenweihe gültig empfangen?, w: Diakonat und Diakonissen, red. L. Scheffczyk, St. Ottilien 2002, s. 91; A. Altana, Teologia e pastorale del diaconato permanente, w: Il diaconato permanente, s. 42; A. Vingt-Trois, Évéques, prêtres et diacres, Paris 2009, s. 65-69.

58 Por. H. Legrand, Bullettin decclésiologie. Le diaconat: renouveau et théologie, RSPT 69 (1985), s. 101; F. Deniau, Le diaconat à la lumière des trois «fonctions» du Christ et de l'Église, selon Vatican II, w: Diaconat XXI' siècle, s. 136; N. Ceci, Il ministero del diacono nel mondo del lavoro, s. 37; H. Renard, Diaconat et service de la charité, s. 117-118.

59 Por. Jan Paweł II, Discorso ai diaconi permanenti in Italia, s. 648-649; A. Kerkvoorde, Per una teologia del diaconato, „Il diaconato in Italia” 88 (1992), s. 30-32; G. P. Cigarini, Servire l'Eucaristia, „Il diaconato in Italia” 91-92 (1993), s. 124; tenże, La formazione dei diaconi permanenti per una prassi ecclesiale di rinnovamento, „Il diaconato in Italia" 110 (1998), s. 40; R. Buccolini, I diaconi: icone viventi dell'amore di Dio per i poveri, „Il diaconato in Italia” 110 (1998), s. 10-11; C. Garzia, Dalla strada al tempio, s. 36; E. Lodi, Le esigenze della diaconia secondo la „lex orandi”, Il diaconato in Italia 88 (1992), s. 23; L. Garbinetto, Il diaconato permanente in America Latina alla luce del documento della Commissione Teologica Internazionale, Roma 2006, s. 163; A. Borras, Il diaconato, vittima della sua novità?Appunti sul diaconato, „La Rivista del Clero Italiano” 5 (2008), s. 335; tenże, Jalous pour une théologie du diaconat, „Esprit et Vie” 112 (2004), s. 11-14; A. Borras, B. Pottier, La grazia del diaconato. Questioni attuali a proposito del diaconato latino, s. 214-218; S. Zardoni, La identità del diacono permanente, „Il diaconato in Italia” 58 (1985), s. 37; tenże, I diaconi nella Chiesa. Ricerca storica e teologica sul diaconato, 
Kościół, który zaniechałby wzięcia odpowiedzialności za będących w potrzebie, stałby się w krótkim czasie bezużyteczny, służący samemu sobie oraz miłujący jedynie tych, którzy jego miłują ${ }^{60}$. Stąd każdy jego członek jest powołany do świadczenia posługi miłosierdzia i powinien stawać się sługą drugiego człowieka ${ }^{61}$. Kościół pełniący dzieła miłosierdzia czyni żywą obecność Chrystusa Sługi w świecie ${ }^{62}$.

Diakoni wypełniają funkcję charytatywną przez zarządzanie w odpowiednim zakresie dobrami i dziełami miłosierdzia Kościoła. Mają oni $\mathrm{w}$ tej dziedzinie zajmować się $\mathrm{w}$ imieniu hierarchii dziełami miłosierdzia i administracją oraz akcją społecznej pomocy ${ }^{63}$. Stąd też, w razie potrzeby, mogą być oni zatrudnieni w biurze ekonoma diecezjalnego ${ }^{64}$

s. 140-148; F. Goyret, L'identità teologica del diaconato (II parte), „Sacrum Ministerium” 1 (2002), s. 40-45; F. Moraglia, Il diacono San Lorenzo ai diaconi del Nuovo Millennio, „Sacrum Ministerium” 1 (2000), s. 97-98; E. Castellucci, I diaconi nella vita della Chiesa: vocazione, carisma. Elementi per una teologia del diaconato, „Orientamenti Pastorali” 7 (2005), s. 107-111; J. Ph. Huet, Le „Ministére Ordonné” chez Yves Marie-Joseph Congar, Roma 2003, s. 125-127; S. Sander, Das Amt des Diakons. Eine Handreichung, s. 21.

${ }^{60}$ Por. A. Altana, Il rinnovamento della vita ecclesiale ed il diaconato, Brescia 1973, s. 123; J. M. Bernett, The Diaconate: A Full and Equal Order, Valley Forge 19952, s. 142; E. Castellucci, I diaconi nella vita della Chiesa: vocazione, carisma, s. 111-115; tenże, Il „Ministero della soglia”. Una lettura teologica del diaconato a partire dal Nuovo Testamento, „Seminarium” 48 (2008), 4, s. 643.

${ }^{61}$ Por. P. McCaslin, M.G. Lawler, Sacrament of Service: A Vision of the Permanent Diaconate Today, New York 1986, s. 6; E. Castellucci, I diaconi nella vita della Chiesa: vocazione, carisma, s. 115-119.

${ }^{62}$ Por. W.T. Donovan, The Sacrament of Service: Understanding Diaconal Spirituality, New York 2000, s. 5.

${ }^{63}$ Por. Paweł VI, Motu proprio Sacrum diaconatus ordinem, 18.06.1967, V, 22, 9, AAS 59 (1967) 702; por. także, Jan Paweł II, Catechesi durante l'Udienza Generale, 13.10.1993, n. 5, w: Insegnamenti 16 (1993) 2, s. 1002-1003; R. Carmagnani, Il diacono, leader di servizio, w: Discernimento... per „dire Dio” oggi. Corsi di formazione permanente per Presbiteri e Diaconi, red. M. Russotto, t. 2, Palermo 2001, s. 13-14; K. Baumgartner, Mit-oder Gegeneinander? Priester, Diakone und Laien im pastoralen Dienst aus pastoraltheologischer Sicht, w: Im Dienst der Gemeinde. Wirklichkeit und Zukunftsgestalt der kirchlichen Ämter, red. S. Demel, L. Gerosa, P. Krämer, L. Müller, Münster 2002, s. 100-101; E. Lodi, Le esigenze della diaconia secondo „lex orandi”, s. 23; W. Kasper, El diácono desde el punto de vista eclesiológico confrontando con los desaflos presentes en la Iglesia y la sociedad, „Boletin OSLAM” 44 (2004), s. 40.

${ }^{64}$ Por. KPK, kan. 494. 
lub być współpracownikami diecezjalnej rady do spraw ekonomicznych ${ }^{65}$.

Posługa diakonów na rzecz ubogich jest znakiem, że Kościół, począwszy od wnętrza swoich struktur hierarchicznych, pragnie być solidarny ze wszystkimi ludźmi w poszukiwaniu ich godności osobistej, moralnej i duchowej. Stawanie się ubogim przez diakona nie zakłada jedynie wyboru ubogich jako uprzywilejowanych podmiotów dzieła zbawienia, ale również patrzenie na Boga, świat i historię z ich punktu widzenia. Bóg, który poleca dawać jałmużnę i udzielać pomocy ubogim, może nawet podobać się, ale Bóg, który wymaga, by znaleźć się w ich położeniu, jest niewygodny i wywołuje zgorszenie. Ta opcja powinna być przekładana na poszukiwanie tych, dla których pomoc jest najbardziej niezbędna, a zatem na obowiązek mądrego odczytywania „znaków czasu” w wymiarze wielkiego horyzontu nadziei zawartego w Apokalipsie: „Oto czynię wszystko nowe” (Ap 21,5). Diakoni winni otaczać swoją troską ludzi lekceważonych, zajmujących niską pozycję społeczną, zrozpaczonych i upośledzonych, ubogich i zaniedbywanych przez parafię, wegetujących na marginesie społeczeństwa i Kościoła. Bezinteresownie służąc tym ludziom oraz wykonując wśród nich pracę, diakoni winni dążyć do wyrwania ich z izolacji i zbliżenia ich do świeckiej i chrześcijańskiej społeczności. Diakoni winni opiekować się tymi ludźmi i nie dopuszczać, by służba chrześcijańskiej miłości była zaniedbywana w parafii. Nie ulega więc wątpliwości, że diakoni, realizując drogę ubóstwa i uczestniczenia w życiu najuboższych, stają się narzędziem zbawienia wszystkich. Duszpasterstwo diakonalne przedstawia się w ten sposób jako czynny znak wpływu na społeczeństwo świeckie, ukierunkowany na wzbudzenie uwagi preferencyjnej na najbardziej ubogich. Tego typu duszpasterstwo oddziałuje także na wybory społeczeństwa i na wybory tych, którzy są wezwani do rządzenia społeczeństwem ${ }^{66}$.

Według Enzo Petrolino, przy opracowywaniu strategii duszpasterskiej w łączności z eklezjologią diakonalną Kościoła ubogich, powinno się koniecznie wziąć pod uwagę uprzywilejowane miejsce ubogich, ich

${ }^{65}$ Por. tamże, kan. 493.

${ }^{66}$ Por. R. Selejdak, Diakonat stały w świetle dokumentów Soboru Watykańskiego, posoborowego Urzędu Nauczycielskiego Kościoła i narodowych „Rationes institutionis diaconorum permanentium", s. 332-333. 
pracę, codzienne życie, uczucia, opinie i aspiracje oraz ciągłą analizę rzeczywistości ludzkiej, aby właściwie odczytać znaki czasu i Boży plan zbawienia. Diakoni mogą pobudzać wspólnotę Kościoła lokalnego do aktywniejszego zaangażowania się $\mathrm{w}$ podejmowanie dzieł miłosierdzia i w ten sposób ukazywać obraz Kościoła, który w swojej całości jest znakiem Bożego miłosierdzia ${ }^{67}$.

Zdaniem Luigiego Sartoriego ${ }^{68}$ posługi miłosierdzia spełnianej przez diakonów nie można sprowadzać jedynie do formy działalności społecznej. Ich posługa „stołom” ma fundament chrystologiczny i eklezjologiczny. Są oni bowiem nie tylko tymi, którzy rozdzielają pokarmy i napoje, ale także sługami Bożego Kościoła i tajemnic Jezusa Chrystusa. Podobną opinię głosi Serafino Zardoni. Według niego posługa miłosierdzia diakona jest przede wszystkim działaniem religijnym, sakramentalnym i mesjańskim, a dopiero w dalszej kolejności socjalnym ${ }^{69}$.

Diakoni mają za zadanie świadczyć, iż miłosierdzie chrześcijańskie stanowi dar Chrystusa dla ludzi, których kocha. Ta miłość, którą Bóg Ojciec przez Chrystusa okazuje ludziom, przekształca człowieka, uzdalnia go do bycia solidarnym z innymi, do niesienia pomocy wszystkim będącym w potrzebie. Czuwanie nad tożsamością apostolską diakonii miłosierdzia oznacza świadczenie o Chrystusie Słudze, który oddaje życie za swoich przyjaciół (por. J 15,13-15) ${ }^{70}$.

67 Por. E. Petrolino, Diakoni, zwiastuni Słowa Bożego, szafarze ołtarza i miłosierdzia, Kraków 2002, s. 73-74; tenże, Diaconi permanenti nella Chiesa del Terzo Millennio, w: Radici... il Mistero del Ministero. Corsi di formazione permanente per Presbiteri e Diaconi, red. M. Russotto, t. 1, Palermo 2001, s. 239-240; tenże, I diaconi per la chiesa del terzo millennio, w: La Chiesa diaconia universale di salvezza, red. G. Bellia, Reggio Emilia 2004, s. 93-95; por. także, M. Piton, Teologia urzędów i diakonat, „Novum” 4-5 (1979), s. 126; A Borras, Jalous pour une théologie du diaconat, s. 37.

${ }^{68}$ Por. L. Sartori, Diaconia della carità nella pastorale della Chiesa locale, Padova 1986, s. 262-264.

69 Por. S. Zardoni, La identità del diacono permanente, s. 37.

70 Por. A. Borras, Il diaconato, vittima della sua novità?, s. 335; Y. Congar, Diakonia $w$ duchu Soboru Watykańskiego II, „Novum” 4-5 (1979), s. 83; M. Piton, Teologia urzędów i diakonat, s. 126; E. Costa, O przywrócenie stałego urzędu diakona, „Novum” 4-5 (1979), s. 165; R. Frattallone, Vocazione al diaconato e direzione spirituale dei diaconi permanenti in Rivista Rogate Ergo, Roma 1997, s. 61-62. 
Dlatego też Dyrektorium o posłudze i życiu diakonów stałych przypomina, iż służba miłosierdzia diakonów stałych obejmuje również działalność „W zakresie wykształcenia chrześcijańskiego, prowadzenia oratoriów, młodzieżowych grup kościelnych i zawodowych grup świeckich, promocji życia na każdym jego etapie i przekształcania świata według porządku chrześcijańskiego"71.

Do diakonów i ich posługi miłosierdzia nawiązuje w swoim nauczaniu również Benedykt XVI. Papież zauważa, iż wybór „siedmiu” dał początek posłudze diakońskiej, która była bardzo konkretna, a równocześnie duchowa. Realizowała podstawowe zadanie Kościoła, którym jest uporządkowana miłość bliźniego ${ }^{72}$. Wraz z utworzeniem kolegium „siedmiu” „ «diakonia» - posługa miłości bliźniego, spełniana zbiorowo w sposób zorganizowany - została już wprowadzona do fundamentalnej struktury Kościoła”73. Zdaniem Benedykta XVI Kościół jest zobowiązany do pełnienia posługi miłosierdzia: „Kościół nie może zaniedbać posługi miłości, tak jak nie może zaniedbać Sakramentów i Słowa [...]. Praktyka miłości wobec wdów i sierot, wobec więźniów, chorych i wszystkich potrzebujących należy do jego istoty $\mathrm{w}$ równej mierze, jak posługa Sakramentów i głoszenie Ewangelii"74.

W przemówieniu do diakonów Rzymu Ojciec Święty Benedykt XVI ukazał nowe formy ubóstwa mające miejsce we współczesnym społeczeństwie. Do nich zaliczył m.in. utratę sensu życia przez wielu ludzi oraz ubóstwo duchowe i kulturowe. Poprzez posługę liturgiczną diakoni powinni również starać się zaradzić wspomnianemu ubóstwu. Biednych winni doprowadzać do ołtarza Chrystusa. Nie powinni jednakże skupiać się jedynie na znaczeniu duchowym ubóstwa, ale mieć w pamięci swoje powołanie do posługi materialnej biednym poprzez świadczenie czynnej miłości. Jedynie mocne potwierdzenie przez diakonów pierwszeństwa ich posługi miłosierdzia zapewni dobre przyjęcie i długą przyszłość przywróconemu diakonatowi. W przeciwnym razie diakonat może znaleźć się w sytuacji

${ }^{71}$ DPŻDS, n. 38; por. A. Montan, Il servizio del diacono in una Chiesa ministeriale, s. 141.

${ }^{72}$ Por. Benedykt XVI, Encyklika Deus caritas est, 25.12.2005, Libreria Editrice Vaticana 2005, s. 21.

73 Tamże.

74 Tamże, n. 22. 
podobnej do tej, która zaistniała w Kościele począwszy od V wieku. Wtedy to diakonat $\mathrm{z}$ jednej strony zaczął być interpretowany jako zagrożenie dla tożsamości prezbiterów, a $\mathrm{z}$ drugiej zaczął być uważany przez ludzi świeckich jako jedna $\mathrm{z}$ nowych form ich klerykalizacji. Ogromnie ważna jest też odpowiednia promocja diakona i ukazywanie jego właściwej tożsamości oraz zapewnienie przyszłym diakonom solidnej formacji ${ }^{75}$.

Z kolei w przemówieniu do kleru diecezji rzymskiej Benedykt XVI wyraził nadzieję, że w każdym czasie, w każdej diecezji, choć w zróżnicowanych sytuacjach, posługa miłosierdzia pozostanie fundamentalną i zasadniczą działalnością diakonów. Jednocześnie nie będzie ona wykluczać innych działań diakonów, jak to przypomina historia Kościoła pierwszych wieków, ukazująca Szczepana przepowiadającego Chrystusa, dającego świadectwo uniwersalności orędzia chrześcijańskiego i w ten sposób będącego poprzednikiem św. Pawła Apostoła w rozpowszechnianiu Słowa Bożego ${ }^{76}$.

Do dawania świadectwa życia w duchu ubóstwa oraz do pełnienia dzieł miłosierdzia materialnych i duchowych wobec ludzi najbiedniejszych, opuszczonych, chorych, starszych wiekiem, zachęca diakonów stałych również papież Franciszek. Ponadto przestrzega ich, aby nie stawali się zgorszeniem dla świata poprzez przesadne przywiązywanie się do pieniędzy oraz niewłaściwe zarządzanie powierzonymi im przez Kościół dobrami materialnymi ${ }^{77}$.

75 Por. Benedykt XVI, Discorso ai diaconi permanenti della Diocesi di Roma, 18.02.2006, w: Insegnamenti 2 (2006) 1, s. 196.

76 Tenże, Udienza al clero della Diocesi di Roma, 23.02.2008, „L'Osservatore Romano” 34 (2008), s. 3: „Quindi spero che in ogni tempo, in ogni diocesi, pur con situazioni diverse, questa [la carità] rimarrà una dimensione fondamentale e anche prioritaria per l'impegno dei diaconi, sia pure non l'unica, come ci mostra anche la Chiesa primitiva, dove i sette diaconi erano stati eletti proprio per consentire agli apostoli di dedicarsi alla preghiera, alla liturgia, alla predicazione. Anche se poi Stefano si trova nella situazione di dover predicare agli ellenisti, agli ebrei, di lingua greca, e così si allarga il campo della predicazione. Egli è condizionato, diciamo, dalle situazioni culturali, dove lui ha voce per rendere presente in questo settore la Parola di Dio e così anche rendere maggiormente possibile l'universalità della testimonianza cristiana, aprendo le porte a san Paolo, che fu testimone della sua lapidazione e poi, in un certo senso, suo successore nella universalizzazione della Parola di Dio".

${ }_{77}$ Por. Franciszek, Incontro con il clero, $i$ religiosi e $i$ diaconi permanenti nel Duomo di Napoli, 21.03.2015, „L'Osservatore Romano” 66 (2015), s. 7. 


\section{ZAKOŃCZENIE}

Diakoni od początku dziejów Kościoła wypełniają diakonię miłosierdzia przez różnoraką działalność charytatywną oraz przez akcje społecznej pomocy, zwłaszcza wobec najbardziej potrzebujących. W wypełnianiu posług miłosierdzia powinni oni naśladować Chrystusa-Sługę, którego są reprezentantami. Realizując drogę ubóstwa i uczestniczenia w życiu najuboższych, stają się też znakiem Kościoła, który począwszy od wnętrza swoich struktur hierarchicznych, pragnie być solidarny ze wszystkimi ludźmi w poszukiwaniu ich godności osobistej, moralnej i duchowej.

Streszczenie. Posługa miłosierdzia najbardziej typową działalnością diakonów stałych. Na mocy przyjętego sakramentu święceń, razem z biskupem i prezbiterami diecezji diakoni uczestniczą $\mathrm{w}$ tych samych funkcjach pasterskich. Funkcje te jednak wykonują w sposób odmienny, służąc i pomagając biskupowi i prezbiterom. To uczestnictwo, jako że wypływa z sakramentu, oznacza, że diakoni służą ludowi Bożemu w imię Chrystusa. Posługa miłosierdzia jest ich podstawową działalnością, ukierunkowaną na niesienie pomocy i udzielanie wsparcia wszystkim członkom Kościoła lokalnego, aby móc uczestniczyć w życiu i misji Kościoła w duchu wspólnoty i według posiadanych charyzmatów. Służba, ponad i poza diecezjalnymi i parafialnymi dziełami miłosierdzia, obejmuje także dzieła miłosierdzia na polu edukacji chrześcijańskiej; animatorów grup, grup młodych ludzi w Kościele, a także profesjonalnych wiernych świeckich; promocję życia na każdym jego etapie, jak też przemianę świata w duchu chrześcijańskim. Na tych płaszczyznach ich służba jest wyjątkowo cenna, bowiem w dobie współczesnej, materialne i duchowe potrzeby człowieka, na które Kościół jest wezwany odpowiedzieć, są rozmaite. $\mathrm{Z}$ tego powodu muszą oni starać się służyć każdemu bez jakiejkolwiek dyskryminacji, zwracając uwagę na tych najbardziej potrzebujących oraz grzeszników, podążając za przykładem Chrystusa Sługi, którego reprezentują. Ich służba miłosierdzia musi człowiekowi dać możliwość doświadczenia miłości Boga, prowadząc go do nawrócenia i otwierając jego serce na łaskę Bożą.

Słowa kluczowe: diakonat; diakon; biskupi; prezbiterzy; diakon stały; tożsamość diakońska; diakonia; diakonia miłosierdzia; Chrystus Sługa; „obsługa stołów”; „siedmiu”; „helleniści”; działalność charytatywna; miłosierdzie chrześcijańskie; wspólnota kościelna; chorzy; ubodzy.

Abstract. Service of mercy as the most typical activity of permanent deacons. By the sacrament of Orders, deacons also, in communion with the Bishop and the diocesan presbyterate, participate in the same pastoral functions, but exercise them in a different way, serving and helping the Bishop and priests. This participation, inasmuch 
as it flows from the sacrament, means that deacons serve the People of God in the name of Christ. The service of mercy is their most typical activity, and is directed to helping and supporting all members of the particular Church to be able to participate in the life and mission of the Church, in a spirit of communion and according to their gifts. The service, above and beyond diocesan or parochial works of charity also embraces works of charity in the field of Christian education; animating speakers, groups of young people in the Church and professional laypeople; the promotion of life at every stage and of the transformation of the world according to the Christian spirit. In these areas their service is particularly valuable because, at the present time, the spiritual and material needs of man, to which the Church is called to respond, are very diverse. For this reason, they must strive to serve everyone without discrimination, giving particular attention to those who are in most need and to sinners, following the example of Christ the Servant, whom they represent. Their service of mercy must enable man to experience the love of God and lead him to conversion, and to open his heart to divine grace.

Keywords: diaconate; deacons; bishops; priests; permanent diaconate; diaconal identity; service; service of mercy; „service at tables”; Christ the Servant; „the seven”; „the Greeks/Hellenists”; charitable activity; Christian mercy; ecclesial community; the sick; the poor. 